\title{
Aplosporella thailandica; a novel species revealing the sexual-asexual connection in Aplosporellaceae (Botryosphaeriales)
}

\author{
Ekanayaka $\mathrm{AH}^{1,2,3,6}$, Dissanayake $\mathrm{AJ}^{1,4}$, Jayasiri $\mathrm{SC}^{1,5}$, To-anun $\mathrm{C}^{6}$, Jones \\ EBG $^{6,7}$, Zhao $Q^{1,2,8}$ and Hyde KD ${ }^{1}$
}

${ }^{1}$ Center of Excellence in Fungal Research, Mae Fah Luang University, Chiang Rai 57100, Thailand.

${ }^{2}$ Key Laboratory for Plant Diversity and Biogeography of East Asia, Kunming Institute of Botany, Chinese Academy of Sciences, Kunming 650201, People's Republic of China.

${ }^{3}$ World Agro forestry Centre East and Central Asia Office, 132 Lanhei Road, Kunming 650201, People's Republic of China.

${ }^{4}$ Institute of Plant and Environment Protection, Beijing Academy of Agriculture and Forestry Sciences, Beijing 100097, People's Republic of China.

${ }^{5}$ Engineering Research Center of Southwest Bio-Pharmaceutical Resources, Ministry of Education, Guizhou University, Guiyang 550025, Guizhou Province, People's Republic of China.

${ }^{6}$ Division of Plant Pathology, Department of Entomology and Plant Pathology, Faculty of Agriculture, Chiang Mai University, Chiang Mai 50200, Thailand.

${ }^{7}$ Department of Botany and Microbiology, College of Science, King Saud University, P.O. Box: 2455, Riyadh 1145, Saudi Arabia.

${ }^{8}$ Biotechnology and Germplasm Resources Institute, Yunnan Academy of Agricultural Science, Kunming, Yunnan, 650223, People's Republic of China.

Ekanayaka AH, Dissanayake AJ, Jayasiri SC, To-anun C, Jones EBG, Zhao Q, Hyde KD 2016 Aplosporella thailandica; a novel species revealing the sexual-asexual connection in Aplosporellaceae (Botryosphaeriales). Mycosphere 7(4), 440-447, Doi 10.5943/mycosphere/7/4/4

\begin{abstract}
Aplosporella thailandica sp. nov. was collected from a dead stem in Chiang Rai, northern Thailand and identified by morphological characteristics and analyses of combined ITS and EF1- $\alpha$ sequence data. This is the first report of a sexual morph with molecular evidence for this genus and the first record of spermatogenesis and chlamydospore associated with the asexual state of this family. The sexual morph of Aplosporella thailandica resembles Bagnisiella and the asexual morph resembles Aplosporella, thus proving the sexual-asexual connection for the first time for this family.
\end{abstract}

Key words - Asexual morph - Bagnisiella - multiloculate - sexual morph

\section{Introduction}

The family Aplosporellaceae, Botryosphaeriales was introduced by Slippers et al. (2013) for Aplosporella and Bagnisiella. According to Hyde et al. (2011) and Liu et al. (2012) Aplosporella is an asexual genus circumscribed by multilocular pycnidial conidiomata embedded in stromatic tissues opening by a communal ostiole. Conidiophores are reduced to hyaline, phialidic conidiogenous cells and conidia are aseptate, ellipsoid to subcylindrical, initially hyaline, thinwalled and smooth, becoming pigmented, thick-walled and spinulose (Sutton 1980). Aplosporella 
species have been recorded from thin, dead twigs and rarely on leaves or thicker branches (Pande \& Rao 1995). The first sexual record of this genus was reported in 1880 by Spegazzini and is based on this description. Slippers et al. (2013) re-described the genus in a new family, Aplosporellaceae.

Bagnisiella is a sexual genus in Aplosporellaceae and characterised by pseudothecial ascomata, mostly multilocular with multi-layered dark brown walls, embedded in stromatic tissue. Asci are bitunicate, mostly with a thick endotunica, clavate, with a well-developed apical chamber and intermixed with pseudoparaphyses. Pseudoparaphyses are hyphoid, hyaline and septate and ascospores are hyaline to pigmented, frequently aseptate, ellipsoid to ovoid and lack mucoid appendages or sheaths (Slippers et al. 2013, Liu et al. 2012, Thambugala et al. 2014).

Recent literature suggests that Aplosporella might be the asexual morph of Bagnisiella (Slippers et al. 2013, Wijayawardene et al. 2014). However, this connection has never been proven in culture (Damm et al. 2007, Pande \& Rao 1995, Slippers et al. 2013).

In this study, we provide detailed morphological descriptions of both sexual and asexual morphs of Aplosporella thailandica sp. nov., supported by a phylogenetic tree with all available sequences of Aplosporellaceae to infer the phylogenetic relationships of Aplosporella thailandica.

\section{Materials \& Methods}

\section{Sample collection, culture preparation and specimen deposition}

A specimen of Aplosporella was collected in Chiang Rai Province, northern Thailand in December 2015. A pure culture was obtained from single spore isolation as described by Chomnunti et al. (2014). The culture was grown on malt extract agar (MEA). Germinating spores were transferred to MEA and incubated at $25{ }^{\circ} \mathrm{C}$ for one week. Cultural characteristics such as mycelium colour, shape and texture were determined. After one week, hyphal tips were transferred to fresh media. The cultures were incubated at $25{ }^{\circ} \mathrm{C}$ under light for one week and growth rate was measured. After 6 weeks, cultures on MEA were checked for asexual structures. The type specimen is deposited in the Mae Fah Luang University Herbarium (MFLU), Chiang Rai, Thailand, and extype culture in Mae Fah Luang University Culture Collection (MFLUCC). An isotype is deposited in Kunming Institute of Botany Herbarium (HKAS). Faces of Fungi numbers and Index Fungorum numbers were registered as described in Jayasiri et al. (2015) and Index Fungorum (2016).

\section{Observation of cultures, sexual morph and asexual morph}

Macroscopic and microscopic characters were recorded. Sections of ascostromata and conidiomata were made with a razor blade, mounted in water and preserved in lacto-glycerol. A Motic SMZ-168 stereo microscope was used to observe the structure of ascostromata and conidiomata. A Nikon ECLIPSE 80i microscope was used to observe microscopic characters. Photomicrographs were recorded with a Canon 450D digital camera fitted to the microscope. Measurements of ascostromata, asci, ascospores, conidiophores, conidiogenous cells and conidia were made from materials mounted in water and the mean values were used in the descriptions. Measurements were made with the Taro soft (R) Image Frame Work v. 0.9.7 and images used for figures were processed with Adobe Photoshop CS6 software (Adobe Systems Inc.).

\section{DNA extraction, PCR and sequencing}

Genomic DNA was extracted directly from ascostromata ta on the natural substrate and from mycelia grown on MEA using a Plant DNA Rapid Extraction Kit (Bio Teke corperation, Beijing, China). The internal transcribed spacers (ITS) were amplified with primers ITS4 and ITS5 (White et al. 1990) while primers EF1-728F and EF1-986R (Carbone \& Kohn 1999) were used to amplify part of the translation elongation factor 1-alpha gene (EF1- $\alpha)$. The PCR mixtures $(25 \mu \mathrm{L})$ contained $\mathrm{ddH}_{2} \mathrm{O}(11 \mu \mathrm{L})$, PCR Master Mix (TIANGEN Co., China) $(11 \mu \mathrm{L} ; 2 \times)$, DNA template $(1 \mu \mathrm{L})$, each primer $(1 \mu \mathrm{L} ; 10 \mu \mathrm{M})$. PCR amplification conditions were as described by Thambugala et al. (2015). The PCR products were viewed on $2 \%$ agarose gels stained with ethidium bromide. PCR products were sequenced by Sunbiotech Company, Beijing, China. 


\section{Sequence alignment and phylogenetic analysis}

Newly generated sequences were subjected to a standard BLAST search of GenBank for preliminary identification. Twenty sequences belonging to two gene regions (ITS, EF1- $\alpha$ ) from representative Aplosporella and Bagnisiella species and the out-group taxon Saccharata proteae (Wakef.) Denman \& Crous., were downloaded from GenBank (Table 1). The newly generated sequences were deposited in GenBank (Table 1) and the alignment in TreeBASE (www.treebase.org, submission ID: S19490). The consensus sequences for each gene were aligned using MAFFT v. $6.864 \mathrm{~b}$ (http://mafft.cbrc.jp/alignment/server/index.html). The single alignments were improved manually where necessary with Bioedit (Hall 1999). Incomplete portions at the ends of the sequences were excluded from the analyses. The single gene alignments of ITS and EF1- $\alpha$ were concatenated into a combined dataset. Maximum parsimony analysis (MP) was performed with PAUP (Phylogenetic Analysis Using Parsimony) v. $4.0 b 10$ (Swofford 2003) for the combined ITS and EF1- $\alpha$ gene regions. Ambiguously aligned regions were excluded from the EF1- $\alpha$ region, gaps in both ITS and EF1- $\alpha$ gene regions were treated as missing data. Trees were inferred using the heuristic search option with TBR branch swapping and 1000 random sequence additions. Branches of zero length were collapsed and all equally most parsimonious trees were saved. Descriptive tree statistics such as tree length [TL], consistency index [CI], retention index [RI], rescaled consistency index $[\mathrm{RC}]$, and homoplasy index $[\mathrm{HI}]$, were calculated. Trees were visualized in TreeView v. 1.6.6 (Page 1996).

Table 1 Taxa used in the phylogenetic analysis and GenBank accession numbers

\begin{tabular}{llll}
\hline \multicolumn{1}{c}{ Species } & \multicolumn{1}{c}{ Strain } & \multicolumn{1}{c}{ GenBank Accession numbers } \\
\cline { 3 - 4 } & & \multicolumn{1}{c}{ ITS } & \multicolumn{1}{c}{ EF 1- } \\
\hline Aplosporella africana & CMW 25424 & KF766196 & EU101360 \\
Aplosporella artocarpi & CPC 22791 & KM006450 & KM006481 \\
Aplosporella hesperidica & CBS 208.37 & JX681069 & N/A \\
Aplosporella javeedii & CFCC 89657 & KM030579 & KM030593 \\
Aplosporella longipes & CFCC 89661 & KM030583 & KM030597 \\
Aplosporella papillata & CBS 121780 & EU101328 & EU101373 \\
Aplosporella prunicola & CBS 121167 & KF766147 & N/A \\
Aplosporella thailandica & MFLU 16-0615 & KX423536 & KX423537 \\
Aplosporella yalgorensis & MUCC 512 & EF591927 & EF591978 \\
Bagnisiella examinans & CBS 551.66 & KF766148 & GU349056 \\
Saccharata proteae & CBS 115206 & KC343004 & KC343730 \\
\hline
\end{tabular}

Abbreviations: CBS: Centraalbureau voor Schimmelcultures, Utrecht, The Netherlands; CFCC: China Forestry Culture Collection Center; CMW: FABI, University of Pretoria, South Africa; CPC Collection of Pedro Crous housed at CBS; MUCC: Culture Collection, Laboratory of Plant Pathology, Mie University, Tsu, Mie prefecture, Japan; MFLUCC: Mae Fah Luang University Culture Collection, Chiang Rai, Thailand. Type and ex-type strains are in bold.

\section{Results}

\section{Phylogenetic analyses}

The combined ITS and EF1- $\alpha$, dataset of all available type/authentic sequences of Aplosoporellaceae consisted of 918 characters (ITS: 1-638, EF1- $\alpha$ : 639-918 - including alignment gaps) for 10 ingroup and 1 outgroup taxa. Of the 918 characters 616 were constant, 215 were variable and parsimony uninformative. Maximum parsimony analysis of the remaining 87 parsimony-informative characters resulted in 425 most parsimonious trees $(\mathrm{TL}=425 ; \mathrm{CI}=0.864$, $\mathrm{RI}=0.592, \mathrm{RC}=0.511, \mathrm{HI}=0.136)$ and the best tree is shown in Fig 1. In this tree two main clades corresponding to two genera of Aplosporellaceae (Fig. 1), namely Aplosporella and Bagnisiella were resolved. Our isolate grouped sister to Aplosporella artocarpi Trakunyingcharoen, Lombard \& Crous. 


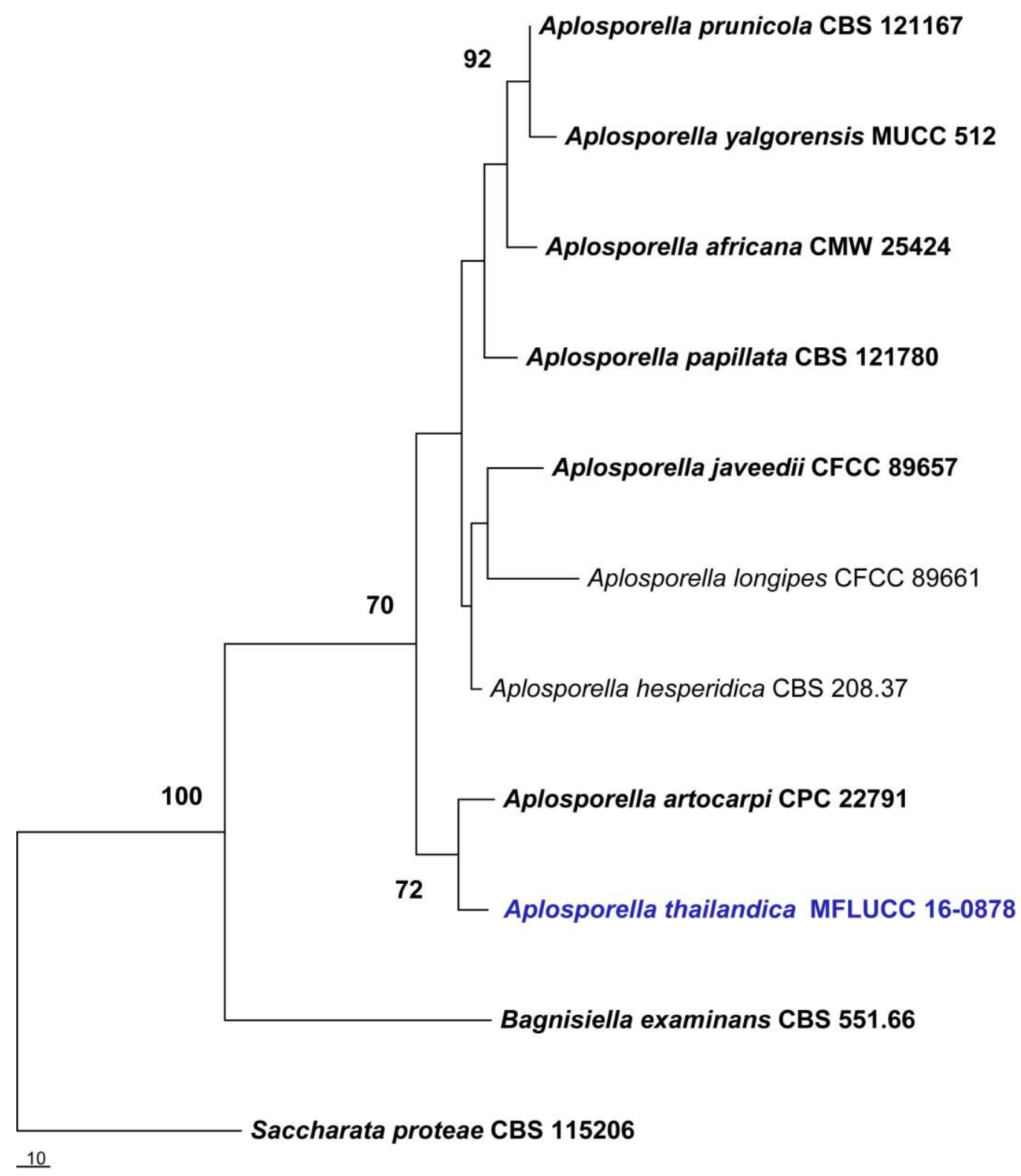

Fig. 1 - Phylogram generated from Maximum Parsimony analysis of all available type/authentic sequences of Aplosporellaceae based on combined ITS and EF1- $\alpha$ sequence data. Parsimony bootstrap support values $\geq 70 \%$ are indicated near the nodes. Strain/culture numbers are given after the taxon names. The newly generated sequences are in blue and ex-type strains are in bold. The tree was rooted with Saccharata proteae (CBS 115206).

\section{Taxonomy}

Aplosporella thailandica Ekanayaka, Dissanayake, Jayasiri \& K.D. Hyde, sp. nov.

Fig 2, 3 Index Fungorum number: IF552228

Facesoffungi number: FoF 02230

Etymology - The specific epithet thailandica refers to the country where the holotype was collected.

Holotype - MFLU 16-0615

Saprobic on dead stems. Sexual morph: Ascostromata 1150-1300 $\times 350-450 \mu \mathrm{m}(\bar{x}=1210 \times 406 \mu \mathrm{m}, \mathrm{n}=$ 10 ), arising singly or in small groups, sessile, erumpent from the substrate, black when fresh, pulvinate, multiloculate, locules rectangular, numerous asci inside each locule. Peridium 50-130 $\mu \mathrm{m}(\bar{x}=73 \mu \mathrm{m}$, $\mathrm{n}=10$ ) composed of large, thin-walled, black cells of textura angularis. Hymenium hyaline to grey. Asci 90 $120 \times 19-24 \mu \mathrm{m}(\bar{x}=108.2 \times 22.5 \mu \mathrm{m}, \mathrm{n}=30)$, bitunicate, 8 -spored, cylindric-clavate, short pedicellate, 


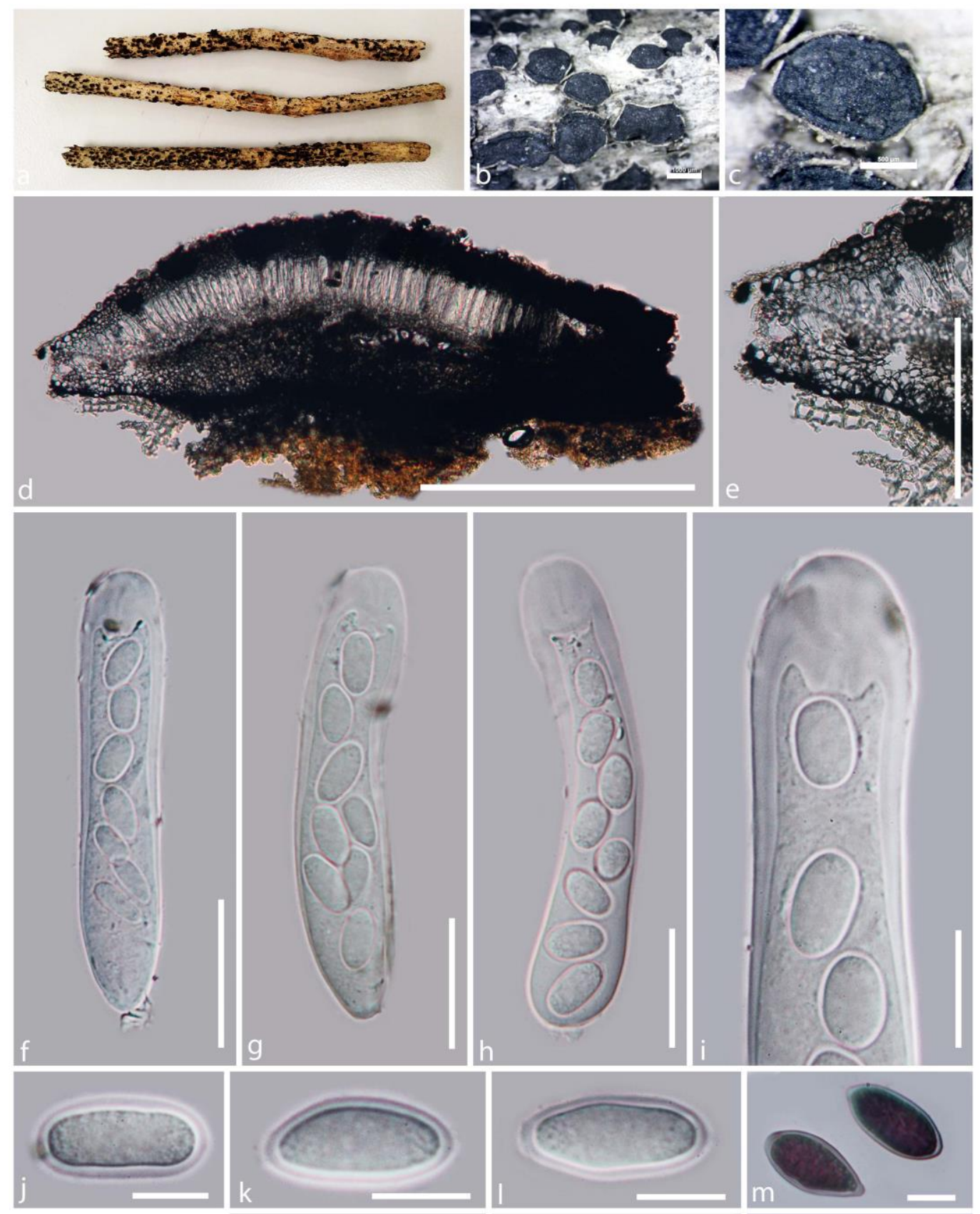

Fig. 2 - Sexual morph of Aplosporella thailandica (MFLU 16-0615). a Herbarium material b, c Ascostromata on wood. d Cross section of an ascostromata. e Vertical section of ascostromata margin. f, g, h Short sessile asci. i Round apical apex. $\mathrm{j}-1$ Ellipsoid ascospores. $\mathrm{m}$ Ascospores in Indian ink. - Bars $b=1000 \mu \mathrm{m}, \mathrm{c}=500 \mu \mathrm{m}, \mathrm{d}=500 \mu \mathrm{m}, \mathrm{e}=150 \mu \mathrm{m}, \mathrm{f}-\mathrm{h}=30 \mu \mathrm{m}, \mathrm{i}=15 \mu \mathrm{m}, \mathrm{j}-\mathrm{m}$ $=10 \mu \mathrm{m}$.

rounded at the apex with a large apical chamber. Ascospores 17-24 $\times 9-10 \mu m(\bar{x}=9.6 \times 21.8 \mu m, \mathrm{n}=40)$, 1-2-seriate, hyaline, ellipsoid to ovate, smooth, thick-walled. Asexual morph: Conidiomata $800-1000 \times$ 600-800 $\mu m(\bar{x}=920 \times 506 \mu m, \mathrm{n}=10)$ on MEA pycnidial, multiloculate, superficial, dark brown to black, globose, covered with hyphae; wall composed dark to light brown textura angularis. Conidiophores absent. Conidiogenous cells hyaline, holoblastic, smooth, cylindrical. Conidia 14-22 $\times 8-14 \mu m(\bar{x}=18.3 \times 11.0$ $\mu m, \mathrm{n}=20$ ) aseptate, initially light brown, smooth-walled, ellipsoidal to subcylindrical, with rounded ends, becoming dark brown (black in mass). Spermatophores reduced to Spermatogenous cells, occurring intermingled among conidiogenous cells in same conidioma, subcylindrical, hyaline, smooth. Spermatia 4-8 $\times 1-3 \mu m(\bar{x}=6.2 \times 2 \mu m, \mathrm{n}=20)$ hyaline, smooth, granular, subcylindrical, straight or slightly curved. Chlamydospores $40-45 \times 25-30 \mu m(\bar{x}=42.3 \times 27.6 \mu m, \mathrm{n}=20)$ brownish green, ellipsoidal to subcylindrical, becoming green. 


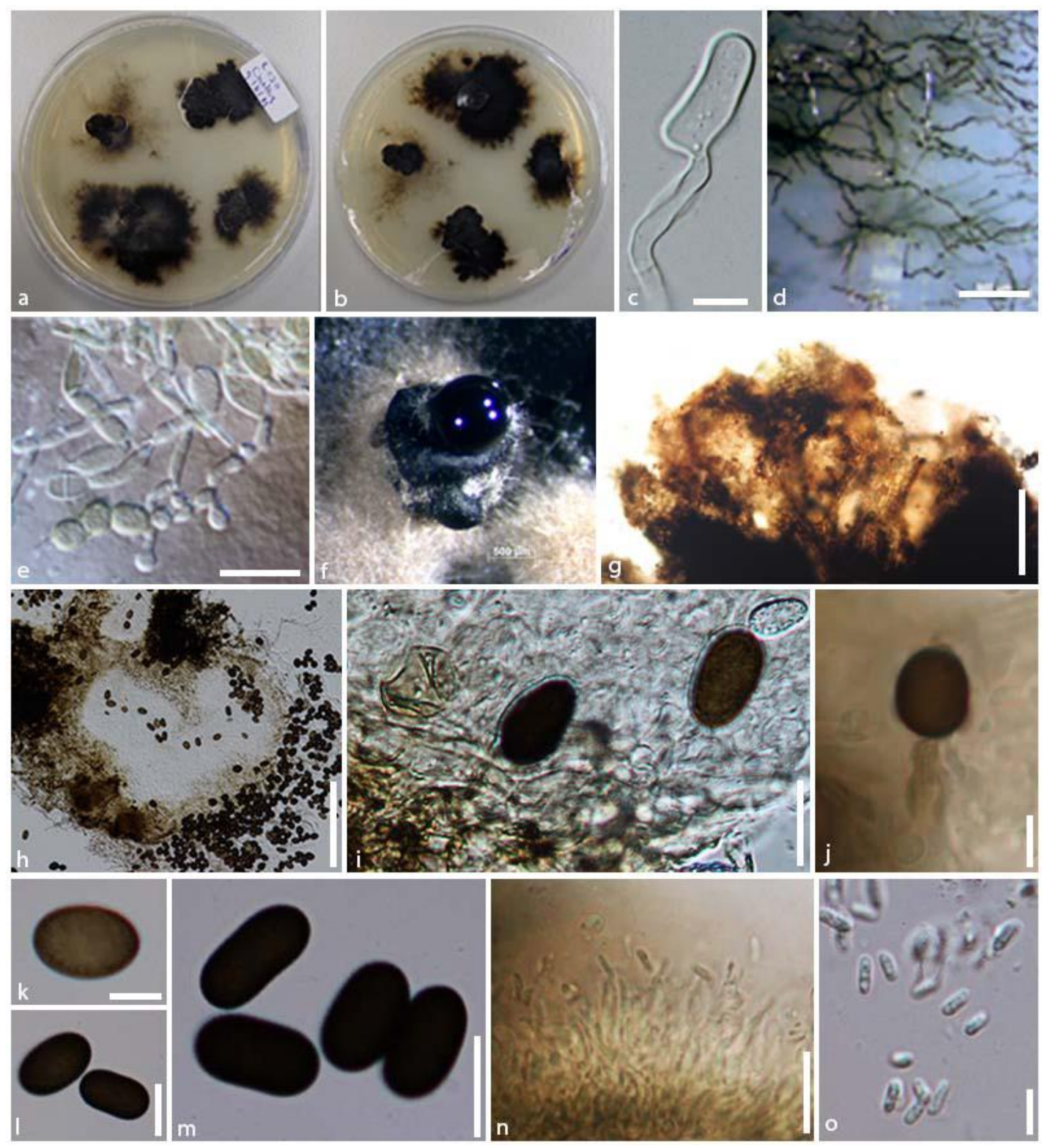

Fig. 3 - Asexual morph of Aplosporella thailandica in culture (MFLUCC 16-0878). a 14-d-old colony on MEA from above. b 14-d-old colony on MEA from below. c Germinated spore on MEA. d 14-d-old hyphae on MEA. e Chlamydospores. f Conidioma in culture. g, h Cross section of multiloculate conidioma. $\mathrm{i}, \mathrm{j}$ Different stages of conidiogenesis. $\mathrm{k}-\mathrm{m}$ Conidia. $\mathrm{n}$ Spermatogenous cells. o Spermatia. - Bars $\mathrm{c}=10 \mu \mathrm{m}, \mathrm{d}=500 \mu \mathrm{m}, \mathrm{e}=60 \mu \mathrm{m}, \mathrm{f}=500 \mu \mathrm{m}, \mathrm{g}=600 \mu \mathrm{m}, \mathrm{h}=100 \mu \mathrm{m}$, $\mathrm{i}=20 \mu \mathrm{m}, \mathrm{j}=20 \mu \mathrm{m}, \mathrm{k}=10 \mu \mathrm{m}, \mathrm{l}=10 \mu \mathrm{m}, \mathrm{m}=20 \mu \mathrm{m}, \mathrm{n}=30 \mu \mathrm{m}, \mathrm{o}=10 \mu \mathrm{m}$.

Cultural characteristics - Ascospores germinating on PDA within $18 \mathrm{~h}$. Colonies on PDA at $25{ }^{\circ} \mathrm{C}$ reached $4 \mathrm{~cm}$ diameter after 14 days, circular, flat or effuse, dense, upper surface initially greenish, becoming blackish green from the center within 7 days. Reverse dark green to black.

Material examined - THAILAND, Mae Fah Luang University, Chiang Rai Province, on dead stems, 20 December 2015, A.H. Ekanayaka (MFLU 16-0615, holotype), ex-type living culture MFLUCC 16-0878.

Notes - The sexual morph of Aplosporella thailandica is similar to Bagnisiella australis Speg., but differs in ascospores with rounded ends in Aplosporella thailandica. The asexual morph of Aplosporella thailandica is similar to Aplosporella artocarpi T. Trakunyingcharoen, L. Lombard \& Crous and to Aplosporella prunicola Damm \& Crous., but differs in the production of spermatia and chlamydospores in culture. 


\section{Discussion}

The present study describes the first record of the sexual-asexual connection within the family Aplosporellaceae and supported by molecular evidence. Moreover this is the first record of spermatogenesis and chlamydospore production within this family. Based on both sexual and asexual morphological characteristics together with DNA sequence data, we introduce a new species in Aplosporellaceae, namely Aplosporella thailandica. Morphological characteristics of this isolate are similar to the description of A. chlorostroma Speg. 1880 (Slippers et al. 2013). However, a comprehensive comparison between these two species was not possible on account of the unavailability of illustrations and detailed descriptions of $A$. chlorostroma. The sexual morph of A. thailandica is morphologically similar to Bagnisiella australis, which forms multiloculate ascostromata, short, apically rounded asci and ellipsoid, hyaline ascospores (Liu et al. 2012, Thambugala et al. 2014). However, they differ in their ascospore characteristics. Bagnisiella australis has oblong and elliptic ascospores with tapered to pointed ends (Thambugala et al. 2014), while $A$. thailandica has ellipsoid to ovate ascospores with rounded ends.

The genera Aplosporella and Bagnisiella are currently assigned to the family Aplosporellaceae, which is typified by Aplosporella chlorostroma (Slippers et al. 2013). The first phylogenetic study to include both genera was conducted by Slippers et al. (2013) and suggested that they should be synonymized, since they occupy a distinct phylogenetic position within Botryosphaeriales with the production of similar multiloculate sporocarps in both asexual and sexual morphs. Although the morphological characters of the sexual morph of both genera are similar, there was insufficient information available on the cultural characteristics and asexual morph characteristics of Bagnisiella to synonymize them (Slippers et al. 2013). However in our study, we have shown that the sexual morph of our isolate resembles Bagnisiella while the asexual morph from culture is morphologically similar to Aplosporella. We thus agree with Slippers et al. (2013) that Bagnisiella should be regarded as a synonym of Aplosporella. Moreover, the cylindrical asci rounded at both ends as seen in $A$. thailandica are morphologically unique in the Botryosphaeriales.

\section{Acknowledgements}

D. Jayarama Bhat is thanked for needful discussion in preparing the text of this manuscript. Anusha H. Ekanayaka is grateful to (Late) Mr. W. Ekanayaka, Mrs. C. Ekanayaka and Mr. A. Surasinghe for their valuable support and encouragement.

\section{References}

Carbone I, Kohn LM. 1999- A method for designing primer sets for speciation studies in filamentous ascomycetes. Mycologia 91, 553-556.

Chomnunti P, Hongsanan S, Aguirre-Hudson B, Tian Q, Peršoh D, Dhami MK, Alias AS, Xu J, Liu X, Stadler M, Hyde KD. 2014- The Sooty Moulds. Fungal Diversity 66, 1-36.

Damm U, Fourie PH, Crous PW. 2007-Aplosporella prunicola, a novel species of anamorphic Botryosphaeriaceae. Fungal Diversity 27, 35-43.

Hall T. 2004 - BioEdit. Ibis Therapeutics, Carlsbad, CA, 92008, USA. http://www.mbio.ncsu.edu/ BioEdit/bioedit.html.

Hyde KD, McKenzie EHC, KoKo TW. 2011 - Towards incorporating anamorphic fungi in a natural classification-checklist and notes for 2010. Mycosphere 2, 1-88.

Index Fungorum. 2016 - http://www.indexfungorum.org/Names/Names.asp. (Accessed on June 2016).

Jayasiri SC, Hyde KD, Ariyawansa HA, Bhat J, Buyck B, Cai L, Dai YC, Abd-Elsalam KA, Ertz D, Hidayat I, Jeewon R, Jones EBG, Bahkali AH, Karunarathna SC, Liu JK, Luangsa-ard JJ, Lumbsch HT, Maharachchikumbura SSN, McKenzie EHC, Moncalvo, JM, GhobadNejhad M, Nilsson H, Pang KA, Pereira OL, Phillips AJL, Raspé O, Rollins AW, Romero AI, Etayo J, Selçuk F, Stephenson SL, Suetrong S, Taylor JE, Tsui CKM, Vizzini A, Abdel- 
Wahab MA, Wen TC, Boonmee S, Dai DQ, Daranagama DA, Dissanayake AJ, Ekanayaka AH, Fryar SC, Hongsanan S, Jayawardena RS, Li WJ, Perera RH, Phookamsak R, de Silva NI, Thambugala KM, Tian Q, Wijayawardene NN, Zhao RL, Zhao Q, Kang JC, Promputtha I. 2015 - The Faces of Fungi database: fungal names linked with morphology, phylogeny and human impacts. Fungal Diversity 74,3-18.

Liu JK, Phookamsak R, Doilom M, Wiki S, Mei LY, Ariyawansa HA, Boonmee S, Chomnunti P, Dai DQ, Bhat DJ, Romero AI, Xhuang WY, Monkai J, Jones EBG, Chukeatirote E, KoKo TW, Zhoa YC, Wang Y, Hyde KD. 2012 - Towards a natural classification of Botryosphaeriales. Fungal Diversity 57, 149-210.

MAFFT v. 6.864b. 2015 - http://mafft.cbrc.jp/alignment/server/index.html (Accessed on December 2015).

Page RD. 1996 - TreeView: an application to display phylogenetic trees on personal computers. Computer Applications in the Biosciences 12, 357-358.

Pande A, Rao VG. 1995 - The genus Aplosporella Speg. (= Haplosporella Speg.) (Coelomycetes) from India. Nova Hedwigia 60, 79-117.

Slippers B, Boissin E, Phillips AJL, Groenewald JZ, Lombard L, Wingfield MJ, Postma A, Burgess T, Crous P. 2013 - Phylogenetic lineages in the Botryosphaeriales: a systematic and evolutionary framework. Studies in Mycology 76, 31-49.

Sutton BC. 1980 - The Coelomycetes. Kew, UK: Common wealth Mycological Institute.

Swofford DL. 2003 - PAUP*: phylogenetic analysis using parsimony (*and other methods), version 4. Sinauer Associates, Sunderland, Massachusetts.

Thambugala KM, Hyde KD, Tanaka K, Tian Q, Wanasinghe DN, Ariyawansa HA, Jayasiri SC, Boonmee S, Camporesi E, Hashimoto A, Hirayama K, Schumacher RK, Promputtha I, Liu ZY. 2015 - Towards a natural classification and backbone tree for Lophiostomataceae, Floricolaceae, and Amorosiaceae fam. nov. Fungal Diversity 74, 199-266.

Thambugala KM, Ariyawansa HA, Li YM, Boonmee S, Hongsanan S, Tian Q, Singtripop C, Bhat JD, Camporesi E, Jayawardena R, Liu ZY, Xu JC, Chukeatirote E, Hyde KD. 2014 Dothideales. Fungal Diversity 68, 105-158.

Vilgalys R, Hester M. 1990 - Rapid genetic identification and mapping of enzymatically amplified ribosomal DNA from several Cryptococcus species. J Bacteriol. 172, 4238-4246.

White TJ, Bruns T, Lee S, Taylor JW. 1990 - Amplification and direct sequencing of fungal ribosomal RNA genes for phylogenetics. In: Innis MA, Gelfand DH, Sninsky JJ, White TJ (eds) PCR protocols: a guide to methods and applications. New York Academic Press. pp 315-322.

Wijayawardene NN, Crous PW, Kirk PM, Hawksworth DL, Boonmee S, Braun U, Dai DQ D'souza MJ, Diederich P, Dissanayake A, Doilom M, Hongsanan S, Jones EBG, Groenewald JZ, Jayawardena R, Lawrey JD, Liu JK, Lücking R, Madrid H, Manamgoda DS, Muggia L, Nelsen MP, Phookamsak R, Suetrong S, Tanaka K, Thambugala KM, Wanasinghe DN, Wikee S, Zhang Y (24), Aptroot A, Ariyawansa HA, Bahkali AH, Bhat DJ, Gueidan C, Chomnunti P, De Hoog GS, Knudsen K, Li WJ, McKenzie EHC, Miller AN, Phillips AJL, Piątek M, Raja HA, Shivas RS, Slippers B, Taylor JE, Tian Q, Wang Y, Woudenberg JHC, Cai L, Jaklitsch WM, Hyde KD. 2014 - Naming and outline of Dothideomycetes 2014 - including proposals for the protection or suppression of generic names. Fungal Diversity 69, 1-55. 